\title{
ANALISIS FRAMING BERITA DEMONSTRASI MAHASISWA SEMARANG TERKAIT KENAIKAN HARGA BBM PADA TV BOROBUDUR
}

\author{
Ayu Nur Irwinesia Putri \\ (Ayunurirwinesiaputri13@gmail.com) \\ (Mahasiswa S1 Program Studi Ilmu Komunikasi Universitas Semarang)
}

\begin{abstract}
The aim of the research to know news framing techniques and ideologies that used Borobudur Television in constructing news Semarang student demonstrations related increases in fuel prices.

The theory base used in this research used framing analysis owned Zhongdang and Kosicki that consist of four devices of there: sintaksis, skrip, tematik and retoris. In addition, the concept of social construction, television news, and local television. The question in this research is how news framing techniques and ideologies in the news constructing student demonstrations.

This research methodology used is descriptive qualitative. Analysis techniques used in this study is methode framing analysis with analysis models owned Zhongdang Pan and Gerald M. Kosicki. This study analyze the news script Semarang student demonstrations related increases in fuel prices broadcast by Borobudur Television period 20-31 March 2012.

It is concluded that news framing techniques used in constructing news Borobudur Television student demonstration it is appropriate with the framing analysis owned Zhongdang because it containts four framing device. And ideologies that are used Borobudur Television appropriate with politics editorials that tends to reveal the reality according to what is happening on the ground.
\end{abstract}

Keywords : Berita demonstrasi mahasiswa, Framing berita televisi, Konstruksi berita.

\section{Pendahuluan}

Media yang lebih banyak menyalurkan informasi ialah media massa. Media massa meliputi media cetak seperti koran, tabloid, majalah, dan media elektronik seperti televisi, radio dan internet. Dalam berbagai analisis tentang kehidupan sosial, ekonomi, dan politik, media sering ditempatkan sebagai salah satu variabel determinan. Media sebagai institusi informasi, dapat pula dipandang sebagai faktor yang paling menentukan dalam proses-proses perubahan sosial dan politik. Oleh karena itu media massa merupakan sumber informasi yang sangat penting bagi manusia.
Ada hal yang penting dan patut diketahui bahwa media tidak pernah bisa membuat pemberitaan yang netral atau tidak mungkin objektif. Hal ini disebabkan karena ada kepentingankepentingan lain, misalnya kepentingan media, pemilik media, atau wartawan itu sendiri, yang terdapat dalam sebuah pemberitaan media massa.

Media memang dituntut untuk membuat berita yang nyata, yaitu fakta yang sesungguhnya terjadi di lapangan. Namun, ada kepentingan-kepentingan lain yang pada akhirnya membuat realitas berita berbeda dengan realitas sesungguhnya. Ada fakta-fakta yang diangkat menjadi berita, ada juga yang tidak. Hal ini dapat dilihat dari siapa 
narasumber yang ditanyai, isu-isu apa yang dominan diangkat dari suatu peristiwa, ataupun posisi berita dalam suatu media. Terkait dengan hal-hal tersebut media dianggap mampu menciptakan second reality.

Setiap media memiliki ideologi masing-masing dalam memaknai dan memahami suatu peristiwa. Dengan perbedaan ideologi, satu fakta yang sama dapat diberitakan secara berbeda oleh media yang berbeda.

Dalam membuat berita, kriteria nilai berita sangat diperlukan oleh wartawan atau reporter untuk memutuskan fakta yang pantas dijadikan berita dan memilih mana yang lebih baik. Salah satu kriteria tersebut adalah proximity atau kedekatan. Dalam media massa lokal, faktor kedekatan berpengaruh pada nilai beritanya karena para reporter atau wartawan mampu melihat masalah dengan jernih atau komprehensif.

Akhir-akhir ini media massa sedang ramai mengangkat pemberitaan tentang kenaikan harga BBM. Bahan Bakar Minyak (BBM) merupakan kebutuhan masyarakat yang sangat penting sehingga saat isu kenaikan BBM muncul, kebijakan tersebut menuai banyak penolakan. Penolakan ini muncul terutama dari kalangan masyarakat menengah ke bawah. Salah satu elemen masyarakat yang menonjol dalam aksi penolakan kenaikan harga BBM adalah mahasiswa. Mahasiswa secara bergantian berunjuk rasa menolak kebijakan tersebut. Demo yang dilakukan oleh mahasiswa juga terjadi di Semarang.

TV Borobudur sebagai salah satu televisi lokal di Semarang juga memberitakan demonstrasi yang dilakukan mahasiswa Semarang untuk menolak kenaikan harga BBM. TV Borobudur seperti halnya media yang lain, juga memiliki perspektif dalam mengkonstruksikan

peristiwa demonstrasi mahasiswa terkait kenaikan harga BBM. Alasan penulis memilih TV Borobudur karena TV Borobudur merupakan televisi lokal swasta pertama di Semarang. Oleh karena itu TV Borobudur mempunyai hubungan emosional yang sudah dibangun sejak lama dengan masyarakat Jawa Tengah, khususnya di wilayah Semarang.

Berdasarkan uraian di atas, peneliti tertarik untuk meneliti bagaimana TV Borobudur mengkonstruksikan demonstrasi mahasiswa Semarang terkait kebijakan naiknya harga BBM. Berita yang akan diteliti adalah berita demonstrasi mahasiswa Semarang terkait kenaikan harga BBM sejak tanggal 20-31 Maret 2012. Hal tersebut dikarenakan pada rentang waktu tersebut TV Borobudur mulai gencar memberitakan demonstrasi mahasiswa Semarang terkait kenaikan harga BBM.

Beberapa permasalahan yang dapat dirumuskan adalah bagaimana teknik yang digunakan oleh TV Borobudur dalam mengkonstruksikan demonstrasi mahasiswa Semarang terkait kenaikan harga BBM dan bagaimana ideologi yang digunakan TV Borobudur dalam mengkonstruksikan demonstrasi mahasiswa Semarang terkait kenaikan harga BBM?

\section{Tinjauan Pustaka}

\section{Teori Framing}

Gagasan tentang framing pada awalnya dikemukakan oleh Baterson tahun 1955. Mulanya frame dimaknai sebagai struktur konseptual atau perangkat kepercayaan yang mengorganisir pandangan politik, kebijakan, dan wacana serta yang menyediakan kategori-kategori standar untuk mengapresiasi realitas. Tahun 1974, Goffman mengembangkan konsep frame sebagai kepingan-kepingan 
perilaku (strips of behaviour) yang membimbing individu dalam membaca realitas (Sobur, 2009: 162).

Entman melihat framing dalam dua dimensi besar yaitu:

"Seleksi isu dan penekanan atau penonjolan aspek-aspek realitas. Kedua faktor ini dapat lebih mempertajam framing berita melalui proses seleksi isu yang layak ditampilkan dan penekanan isi beritanya. Perspektif wartawanlah yang akan menentukan fakta yang dipilihnya, ditonjolkannya, dan dibuangnya. Dibalik semua ini, pengambilan keputusan mengenai sisi mana yang ditonjolkan tentu melibatkan nilai dan ideologi para wartawan yang terlibat dalam produksi sebuah berita" (Sobur, 2009: 163).

Begitu pula dengan TV Borobudur, dalam proses pembuatan berita para wartawan maupun editor mempunyai nilai dan ideologi tersendiri dalam pembuatan berita. Hal tersebut yang akan menentukan fakta mana yang akan dipilihnya, ditonjolkan dan yang dibuang. Maka berita yang dibuat oleh TV Borobudur dengan media yang lainnya tentunya berbeda.

\section{Teori Konstruksi Sosial}

Menurut Von Glaserfeld:

"Konstruktivisme adalah salah satu filsafat pengetahuan yang menekankan bahwa pengetahuan adalah bentukan (kontruksi) kita sendiri. Pengetahuan bukan tiruan dari realitas, bukan juga gambaran dari dunia kenyataan yang ada. Pengetahuan merupakan hasil dari konstruksi kognitif melalui kegiatan seseorang dengan membuat struktur, kategori konsep, dan skema yang diperlukan untuk membentuk pengetahuan tersebut" (Eriyanto, 2007: 47-63).
Konstruktivisme dilihat sebagai sebuah kerja kognitif individu untuk menafsirkan dunia realitas yang ada, karena terjadi relasi sosial antara individu dengan lingkungan atau yang ada disekitarnya. Kemudian individu membangun sendiri pengetahuan atas realitas yang dilihatnya itu, berdasarkan pada struktur pengetahuan yang telah ada sebelumnya, yang oleh Piaget (psikolog kognitif) disebut dengan skema atau skemata. Konstruktivisme macam ini yang oleh Berger dan Luckman disebut dengan konstruksi sosial (Eriyanto, 2007: 47-63).

Dari pemaparan tersebut menunjukkan bahwa tidak ada realitas sosial yang mempunyai obyektivitas mutlak dalam pandangan konstruktivisme. Begitu pula dengan TV Borobudur yang tidak mungkin obyektif dalam memaparkan realitas yang terjadi di masyarakat. Tentunya para wartawan maupun redaktur TV Borobudur mempunyai pandangan sendiri dalam melihat suatu peristiwa.

\section{Berita Televisi}

Charnley dan James M. Neal menuturkan, berita adalah laporan tentang suatu peristiwa, opini, kecenderungan, situasi, kondisi, interpretasi yang penting, menarik, masih baru dan harus secepatnya disampaikan kepada khalayak (Errol Jonathans dalam Mirza) (Sumandiria, 2008: 64).

Dalam definisi jurnalistik, seperti dikutip Assegaff dikatakan:

"Berita adalah laporan tentang fakta atau ide yang termasa, yang dipilih oleh staf redaksi suatu harian untuk disiarkan, yang dapat menarik perhatian pembaca, entah karena dia luar biasa, entah karena penting atau akibatnya, entah pula karena dia mencakup segi-segi human interest 
seperti humor, emosi, dan ketegangan" (Sumandiria, 2008: 64).

\section{Metodologi Penelitian}

Metodologi yang digunakan penulis adalah kualitatif deskriptif dengan menggunakan analisis framing milik Zhongdang Pan dan Gerald M. Kosicki. Melalui model analisis tersebut berita akan dibingkai melalui perangkat framing yang dibagi dalam empat struktur besar, yaitu Sintaksis, Skrip, Tematik, dan Retoris (Sobur, 2009: 175).

Struktur sintaksis berhubungan dengan bagaimana wartawan menyusun peristiwa, pernyataan, opini, kutipan, pengamatan atas peristiwa ke dalam bentuk susunan kisah berita. Struktur skrip melihat bagaimana strategi bercerita atau bertutur yang dipakai wartawan dalam mengemas peristiwa. Struktur tematik berhubungan dengan cara wartawan mengungkapkan pandangannya atas peristiwa ke dalam proposisi, kalimat, atau hubungan antar kalimat yang membentuk teks secara keseluruhan. Struktur retoris berhubungan dengan cara wartawan menekankan arti tertentu. Dengan kata lain, struktur retoris melihat pemakaian pilihan kata, idiom, grafik, gambar, yang juga dipakai guna memberi penekanan pada arti tertentu (Sobur, 2009: 175-176).

Peneliti memilih menggunakan analisis tersebut karena analisis framing digunakan untuk mengetahui teknik pembingkaian berita yang digunakan oleh TV Borobudur. Selain itu framing milik Zhongdang dan Kosicki memiliki 4 perangkat yang digunakan untuk menganalisis naskah berita. Dalam perangkat atau struktur tersebut terdapat beberapa elemen lagi yang digunakan untuk menganalisis lebih detail lagi mengenai isi berita demonstrasi mahasiswa. Sehingga pembingkaian yang digunakan oleh TV Borobudur dalam isi berita demonstrasi mahasiswa bisa nampak jelas dan detail.

Sumber data primer menurut Lofland dalam (Lexy J. Moleong, 2007: 157) : "Sumber data utama dalam penelitian kualitatif ialah kata-kata dan tindakan selebihnya adalah data tambahan seperti dokumen dan lainlain. Berkaitan dengan hal itu pada bagian ini jenis datanya dibagi kedalam kata-kata dan tindakan, sumber data tertulis, foto dan statistik".

Sumber data sekunder menurut Lexy J. Moleong (2007: 159) dikatakan bahwa: "Sumber diluar kata dan tindakan merupakan sumber kedua. Dilihat dari segi sumber data, bahan tambahan yang berasal dari sumber tertulis dapat dibagi atas sumber buku dan majalah ilmiah, sumber dari arsip, dokumen pribadi, dan dokumen resmi".

Penelitian ini menggunakan pengembangan validitas trianggulasi seperti yang dikatakan (Patton dalam Gunawan, 2005: 24). Disebutkan ada empat macam trianggulasi, yaitu trianggulasi data, metode, peneliti, dan teoritis. Selanjutnya dalam penelitian ini digunakan trianggulasi data atau trianggulasi sumber, yaitu melihat sesuatu yang sama dari berbagai perspektif yang berbeda. Melalui trianggulasi data tersebut diperoleh informasi yang lengkap, mendalam, serta komprehensif.

\section{Hasil Penelitian Analisis Framing}

Di bawah ini adalah hasil penelitian analisis framing terhadap beberapa berita tentang demonstrasi mahasiswa Semarang terkait kenaikan harga BBM yang sudah dipilih peneliti. Berita yang dipilih untuk analisis adalah berita yang memiliki kriteria yang ditetapkan peneliti. Berita tentang demonstrasi 
mahasiswa di TV Borobudur periode 20 - 31 Maret 2012. Pertama kategori demonstrasi, yang dipilih adalah demonstrasi yang dilakukan oleh mahasiswa terutama mahasiswa Semarang untuk menolak kenaikan harga BBM. Kedua, demonstrasi yang dilakukan seminggu sebelum penetapan hingga sehari sebelum ditetapkannya kenaikan harga BBM oleh Pemerintah. Dalam rentang waktu tersebut TV Borobudur mulai gencar memberitakan demonstrasi mahasiswa Semarang terkait kenaikan harga BBM. Atas dasar tersebut, peneliti memilih beberapa berita yang diteliti dalam analisis framing.

\section{Frame: Demonstrasi Berlangsung} Ricuh, 27 Maret 2012

\begin{tabular}{|l|l|}
\hline $\begin{array}{l}\text { Perangkat } \\
\text { Framing }\end{array}$ & Hasil Analisis \\
\hline Sintaksis & $\begin{array}{l}\text { Pada Lead berita } \\
\text { menunjukkan bahwa } \\
\text { aksi demo mahasiswa } \\
\text { berlangsung ricuh. }\end{array}$ \\
\hline Skrip & $\begin{array}{l}\text { Nilai berita yang } \\
\text { ditonjolkan adalah } \\
\text { "What \& How". }\end{array}$ \\
\hline Tematik & $\begin{array}{l}\text { Detail berita yang } \\
\text { ditampilkan adalah } \\
\text { kericuhan mahasiswa. }\end{array}$ \\
\hline Retoris & $\begin{array}{l}\text { Penekanan terlihat } \\
\text { pada kata "aksi saling } \\
\text { dorong", "membakar } \\
\text { bendera". }\end{array}$ \\
\hline
\end{tabular}

Peneliti memaknai keseluruhan isi berita "Demonstrasi Berlangsung Ricuh", framing beritanya adalah aksi anarkis mahasiswa sebagai bentuk penolakan atas rencana Pemerintah yang akan menaikkan harga BBM.

Frame : Aksi Mogok Makan, 28 Maret 2012

\section{\begin{tabular}{|l|l|}
\hline Perangkat & Hasil Analisis \\
\hline
\end{tabular}}

\begin{tabular}{|l|lr|}
\hline Framing & \multicolumn{2}{|c|}{} \\
\hline Sintaksis & $\begin{array}{l}\text { Pada Lead berita } \\
\text { menunjukkan } \\
\text { mahasiswarragai } \\
\text { subjek sebagai } \\
\text { melakukan aksi demo. }\end{array}$ \\
\hline Skrip & $\begin{array}{l}\text { Nilai berita yang } \\
\text { ditonjolkan adalah } \\
\text { "What". }\end{array}$ \\
\hline Tematik & $\begin{array}{l}\text { Detail berita yang } \\
\text { ditampilkan adalah } \\
\text { aksi mogok makan } \\
\text { mahasiswa. }\end{array}$ \\
\hline Retoris & $\begin{array}{l}\text { Pada judul berita } \\
\text { menimbulkan makna } \\
\text { mahasiswa terpaksa } \\
\text { melakukan aksi mogok } \\
\text { makan. }\end{array}$ \\
\hline
\end{tabular}

Peneliti memaknai keseluruhan isi berita "Aksi Mogok Makan", framing beritanya adalah mahasiswa terpaksa melakukan aksi mogok makan dengan harapan aspirasi mereka didengarkan oleh Pemerintah.

Frame : Lempar Air Dalam Aksi Demonstrasi, 29 Maret 2012

\begin{tabular}{|c|c|}
\hline Perangkat & Hasil Analisis \\
\hline Sintaksis & $\begin{array}{l}\text { Pada Lead berita } \\
\text { menunjukkan aksi } \\
\text { demo tak henti- } \\
\text { hentinya dilakukan } \\
\text { oleh mahasiswa. }\end{array}$ \\
\hline Skrip & $\begin{array}{l}\text { Nilai berita yang } \\
\text { ditonjolkan adalah } \\
\text { "How". }\end{array}$ \\
\hline Tematik & $\begin{array}{l}\text { Penonjolan terlihat } \\
\text { dari pihak mahasiswa } \\
\text { yang melakukan demo. }\end{array}$ \\
\hline Retoris & $\begin{array}{l}\text { Penekanan kata "aksi } \\
\text { lempar } \\
\text { menunjukkan air" } \\
\text { anarkis mahasiswa. }\end{array}$ \\
\hline
\end{tabular}

Peneliti memaknai keseluruhan isi berita "Lempar Air Dalam Aksi 
Demonstrasi", framing beritanya adalah untuk melampiaskan kemarahan mahasiswa melakukan aksi lempar air, dengan harapan air tersebut dapat mensucikan hati dan pikiran para pejabat.

\section{Frame : Mahasiswa Berbaring Di} Jalan Pengapon, 29 Maret 2012

\begin{tabular}{|l|l|}
\hline $\begin{array}{l}\text { Perangkat } \\
\text { Framing }\end{array}$ & Hasil Analisis \\
\hline Sintaksis & $\begin{array}{l}\text { Pada Lead berita } \\
\text { menunjukkan bentrok } \\
\text { yang terjadi antara } \\
\text { mahasiswa dan Polisi. }\end{array}$ \\
\hline Skrip & $\begin{array}{l}\text { Nilai berita yang } \\
\text { ditonjolkan adalah } \\
\text { "What". }\end{array}$ \\
\hline Tematik & $\begin{array}{l}\text { Detail beritanya adalah } \\
\text { aksi blokir jalan yang } \\
\text { dilakukan } \\
\text { mahasiswa. }\end{array}$ \\
\hline Retoris & $\begin{array}{l}\text { Penekanan oleh } \\
\text { "terlibat bata } \\
\text { "aksi saling dorong", } \\
\text { menunjukkan aksi } \\
\text { anarkis mahasiswa. }\end{array}$ \\
\hline
\end{tabular}

Peneliti memaknai keseluruhan isi berita "Mahasiswa Berbaring Di Jalan Pengapon", framing beritanya adalah dengan adanya aksi mahasiswa yang berbaring di Jalan Pengapon maka mengakibatkan sejumlah truk tangki terlambat mensuplai BBM ke beberapa SPBU.

Frame : Aksi Ricuh Di Jalan Walisongo, 30 Maret 2012

\begin{tabular}{|l|lr|}
\hline $\begin{array}{l}\text { Perangkat } \\
\text { Framing }\end{array}$ & \multicolumn{3}{|l|}{ Hasil Analisis } \\
\hline Sintaksis & $\begin{array}{l}\text { Pada judul } \\
\text { sudah }\end{array}$ & $\begin{array}{l}\text { berita } \\
\text { aksi } \\
\text { menyebabkan } \\
\text { kericuhan. }\end{array}$ \\
\hline Skrip & $\begin{array}{l}\text { Nilai berita } \\
\text { ditonjolkan }\end{array}$ \\
\hline
\end{tabular}

\begin{tabular}{|l|l|}
\hline & "What". \\
\hline Tematik & $\begin{array}{l}\text { Detail beritanya adalah } \\
\text { aksi kericuhan dan } \\
\text { bentrok antara } \\
\text { mahasiswa dengan } \\
\text { aparat kepolisian. }\end{array}$ \\
\hline Retoris & $\begin{array}{l}\text { Penekanan kata } \\
\text { "lempar batu", } \\
\text { "pelemparan batu dan } \\
\text { kayu", "tembakan gas } \\
\text { air mata", hal tersebut } \\
\text { menunjukkan bentrok } \\
\text { yang terjadi antara } \\
\text { mahasiswa dan Polisi. }\end{array}$ \\
\hline
\end{tabular}

Peneliti memaknai keseluruhan isi berita "Aksi Ricuh Di Jalan Walisongo", framing beritanya adalah aksi demo terus dilakukan oleh mahasiswa untuk menentang rencana kenaikan harga BBM dan berujung bentrok dan kericuhan.

\section{Frame : Demo Blokir Jalan} Pahlawan, 31 Maret 2012

\begin{tabular}{|l|l|}
\hline $\begin{array}{l}\text { Perangkat } \\
\text { Framing }\end{array}$ & Hasil Analisis \\
\hline Sintaksis & $\begin{array}{l}\text { Pada judul berita } \\
\text { menunjukkan } \\
\text { mahasiswa memblokir } \\
\text { jalan saat demonstrasi. }\end{array}$ \\
\hline Skrip & $\begin{array}{l}\text { Nilai berita yang } \\
\text { ditonjolkan adalah } \\
\text { "What". }\end{array}$ \\
\hline Tematik & $\begin{array}{l}\text { Detail beritanya adalah } \\
\text { aksi blokir jalan yang } \\
\text { dilakukan } \\
\text { mahasiswa. }\end{array}$ \\
\hline Retoris & $\begin{array}{l}\text { Tidak ada penekanan } \\
\text { tertentu, isi berita } \\
\text { diceritakan secara } \\
\text { berkesinambungan. }\end{array}$ \\
\hline
\end{tabular}

Peneliti memaknai keseluruhan isi berita "Demo Blokir Jalan Pahlawan", framing beritanya adalah aksi demo mahasiswa sebagai bentuk penolakan atas keputusan Pemerintah yang 
menunda kenaikan harga BBM, bukannya membatalkan kenaikan harga BBM.

\section{Kesimpulan}

Penelitian ini menghasilkan beberapa kesimpulan, antara lain:

1. Dalam pembingkaian berita demonstrasi mahasiswa Semarang terkait rencana kenaikan harga BBM di TV Borobudur, dalam siaran berita "Jendela Jateng Sore", pembingkaian demonstrasi mahasiswa setelah diteliti menggunakan analisis framing milik Zhongdang dan Kosicki sudah sesuai dengan perangkat yang ada didalamnya. Pada struktur sintaksis sudah menunjukkan isi berita bahwa aksi demonstrasi mahasiswa diwarnai dengan kericuhan. Pada struktur skrip, berita tersebut berhubungan langsung dengan komunal pemirsa karena subjek yang melakukan demonstrasi adalah mahasiswa Semarang dan TV Borobudur berada di Semarang dan siarannya di wilayah Semarang dan sekitarnya. Pada struktur tematik, detail berita ditulis secara jelas yaitu mengenai aksi-aksi yang dilakukan mahasiswa saat demonstrasi terutama aksi anarkis mahasiswa, dan kalimatnya ditulis berhubungan satu sama lain. Pada struktur retoris, TV Borobudur memberikan penekanan arti tertentu pada isi berita seperti penekanan pada kata-kata "aksi saling dorong", "bakar ban", "lempar batu".

Dalam pengkonstruksian berita demonstrasi mahasiswa, TV Borobudur menggunakan bahasa yang cukup lugas dan tegas untuk mengungkapkan
Pengkonstruksian tersebut juga terlihat dari pemilihan fakta yaitu menampilkan berlangsungnya demonstrasi mahasiswa termasuk aksi-aksi anarkis yang dilakukan mahasiswa. Kemudian dalam pemilihan sumber berita yang dipilih adalah perwakilan mahasiswa yang melakukan demonstrasi sebagai narasumber. Sedangkan untuk pemakaian kata yaitu TV Borobudur menggunakan kata-kata yang tegas dan lugas untuk mengungkapkan fakta sesuai dengan apa yang terjadi di lapangan.

2. Politik redaksional TV Borobudur mencerminkan ideologi yang digunakan TV Borobudur untuk mengungkapkan realitas sesuai dengan peristiwa di lapangan dipilih untuk melihat dinamika dari mekanisme sosial yang sedang terjadi. Unsur kedekatan atau proximity menjadi nilai berita yang kuat mengapa TV Borobudur menempatkan berita demonstrasi mahasiswa terkait rencana kenaikan harga BBM sebagai sesuatu hal yang penting. TV Borobudur yang merupakan media yang berada dibawah Kompas Gramedia Grup, memposisikan sebagai televisi Jawa Tengah, dalam pemberitaan demonstrasi mahasiswa Semarang terkait rencana kenaikan harga BBM memiliki unsur kedekatan dengan para pembacanya yang selanjutnya disiarkan dalam siaran berita Jendela Jateng Sore. Seperti yang sudah dijelaskan sebelumnya, ideologi TV Borobudur dipengaruhi oleh politik redaksionalnya. Sehingga beritaberita yang dibuat oleh TV Borobudur sesuai dengan realita 
atau sesuai dengan apa yang terjadi di lapangan.

\section{Daftar Pustaka}

A.S. Haris Sumandiria. 2008. Jurnalistik Indonesia Menulis Berita dan Feature Panduan Praktis Jurnalis Profesional. Bandung: Simbiosa Rekatama Media.

Alex Sobur. 2009. Analisis Teks Media Suatu Pengantar untuk Analisis Wacana, Analisis Semiotik, dan Analisis Framing. Bandung: PT. Ramaja Rosdakarya.
Eriyanto. 2007. Analisis Framing Konstruksi, Ideologi dan Politik Media. Yogyakarta: LkiS.

Gunawan Witjaksana. 2009. PokokPokok Pemikiran Dalam Metodologi Penelitian Komunikasi Kualitatif. Buku Ajar Ilmu Komunikasi USM.

Iswandi Syahputra. 2011. Rahasia Simulasi Mistrik Televisi. Yogyakarta: Pustaka Pelajar.

Lexy J. Moleong, M.A. 2007. Metodelogi Penelitian Kualitatif. Bandung: PT. Remaja Rosdakarya. 